\title{
野生植物が複雑な季節変化を 感じ取る仕組み
}

植物は、温度や日長の変化を感知して、ほぼ決まった季節に花を咲かせる。ただし、 自然の気温変化はあいまいで、春なのに真冬日に逆戻りといったこともしばしば起 きる。植物はこうした「季節の誤差」をどのようにとらえ、どのように処理してい るのか。工藤洋博士らによって、そのメカニズムの一端が解明された。

一 Nature ダイジェスト：植物が季 節を感じて花を咲かせる仕組みについ て、これまでどのようなことがわかって いたのでしょうか?

工藤 : 一口に花といっても、形態や生態 は種によって実にさまざまです。実験室 の研究では、アブラナ科のシロイヌナ ズナがよく使われています。1 年生の草 本で、世代期間が 2 か月と極めて短い、 丈が 10〜 30 センチメートルと扱いや すい、遺伝子改変が容易、といった多く の利点をもつからです。さらに、ゲノム サイズが小さく、既に全ゲノムの解読が 済んでいるため、配列や遺伝子機能に関 する詳細なデー夕も集まってきていると いう背景もあります。

植物が季節を感じて花を咲かせること を花成といいます。花成の仕組みは、こ のシロイヌナズナを用いて詳しく研究さ れており、60以上の遺伝子が関与して
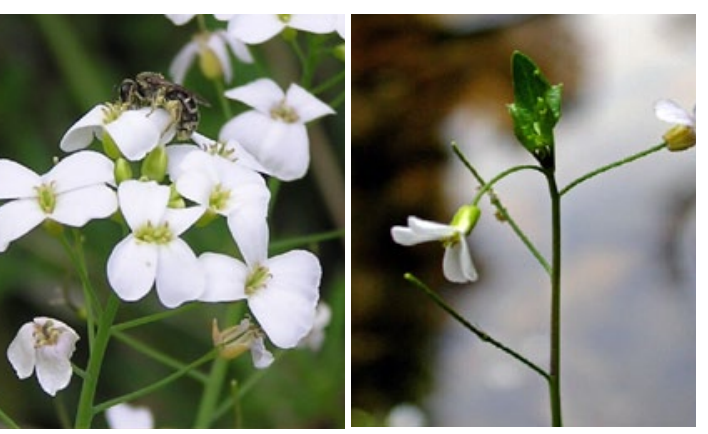

写真 1 兵庫県多可町の調査地に生育する ハクサンハタザオの花。ハナバチの仲間など が訪花して花粉を媒介するため、決まった季 節に開花することが繁殖を成功させるため に重要である(左)。花茎の先端から葉が再 展開するというおもしろい性質をもつ（右）。
いること、これらの遺伝子のネットワー クを動かす重要なシグナルが「日長」と 「温度」の変化にあることなどがわかっ ています。シロイヌナズナでは、気温が 高い間は、あるタンパク質 (FLC 転写 因子）が働くことで花成を抑制するブ レーキがかけられています。逆に、気温 の低い時期が続くと、このタンパク質の 発現量が減り、ブレーキがゆるんで花成 が進みます。一方で、日照時間が長くな ると、葉に特定のタンパク質 (CO タン パク質）が蓄積されるようになり、それ が遺伝子ネットワークの下流にある別の 遺伝子（FT 遺伝子など）の発現を促す ことでも花成が進みます。つまり、野生 のシロイヌナズナは、気温と日長の変化 で春の到来を感知し、2〜4月ごろに、 白くて小さな花を咲かせていることにな ります。

\section{環境誤差に対応する野生植物}

一今回は、野生のハクサンハタザオ を研究対象にされましたが。

私は、予測不能の複雑な環境下にある植 物が、どのようにして季節を感じ、決まっ たころに花を咲かせるのかという点に興 味をもっています。例えば春になったと いっても、今週が先週よりも寒い、とき に真冬日になるといったことがよくあり ます。植物はこうした「環境の誤差」を どのように感知して、修正しているの か。その機能を検証したいと思ったので す。そのためには、実際に野外で自然に 生育している植物をそのままの状態で研 究することが重要と考えました。日本で

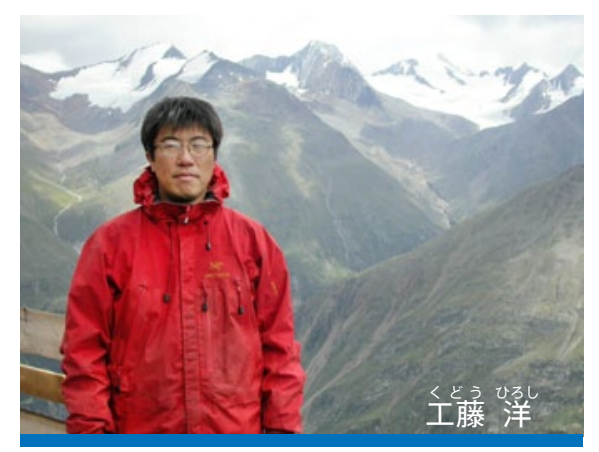

見られるシロイヌナズナは外来のものな ので、シロイヌナズナの近縁種で各地に 自生するハクサンハタザオを使うことに したのです。

ハクサンハタザオは開けた場所に生育 し、重金属耐性をもつので鉱山跡地に多 く見られます。 3 月中旬から 5 月中旬ま で、比較的長い期間、花を咲かせます。 そのゲノムはシロイヌナズナによく似て おり、今回の研究では、シロイヌナズナ の情報がそのまま使えました。ハクサン ハタザオは多年草なので、動物に食べら れたり枯れたりしないかぎり、何年でも 生き続けることができます。また、花が 終わると茎の先端（茎頂）に葉をつけ、 茎頂ごと地面に倒れて、そこから芽を出 すというユニークな仕組みをもつていま す。つまり、花を咲かせる仕組みだけで なく、花をやめる仕組みをも研究するこ とができる非常におもしろい植物です。 種子でも増えますが、このようにしてク ローンでも増えることで、生き延びるた めの保険がかけられているといえます。

具体的にどのような調査や実験を されましたか。

ハクサンハタザオが自生している兵庫県 茤哿彭に調査地を作り、大型の株(クロー ン)を 6 個体決めました。そして、 2 年間、 1 週間おきに計 96 回、若い葉を 1 個体 当たり 1 枚ずつ採集し、実験室に持ち 帰って AhgFLCという遺伝子 (シロイ ヌナズナの FLC 遺伝子に相当）の発現 を調べ続けました。今回は温度に着目し、 その変化、AhgFLC の発現量、開花の関 


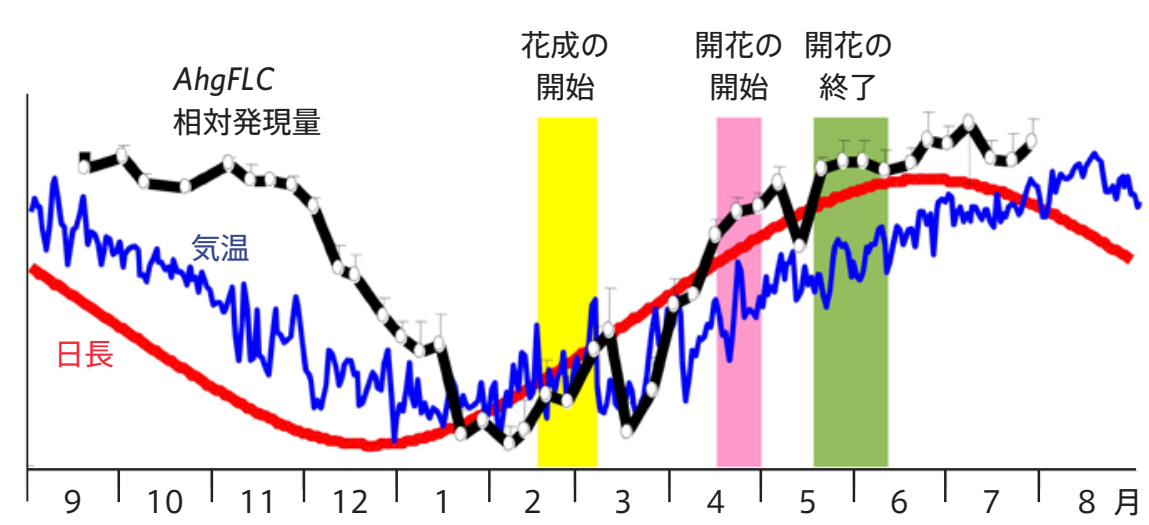

図 1 AhgFLC の季節変化。

AhgFLC の発現量は、12 月ころからゆるやかに減り始め、2 3 月にかけて最小になり、その後、 花成と開花がみられた。春にゆるやかに増え、ピークに達すると開花が終了した。夏の間は 高く保たれ、冬が近づくと再び減り始めるといったサイクルがみられた。

係をみようと思ったのです。私たちは、 花成が多少の寒暖の差には惑わされない という事実から、ハクサンハタザオが「頑 健性」とでもよぶべき仕組みをもち、直 近の過去に経験した温度の情報をどこか に蓄積していると仮定しました。

\section{仮説との整合性は 80 パーセント以上}

——解析の結果、どのようなことがわ かったのでしょう。

まず、ハクサンハタザオの AhgFLC にシ ロイヌナズナの FLC と同様の機能があ ることを確かめました。FLC はシロイヌ ナズナの植物体全体で発現し、葉におい て「花成に特に重要な遺伝子 ( FT 遺伝 子)」の機能を抑制し、花成が進まない ようにブレーキをかけますが、AhgFLC も同じょうに㗢いているょうです。次 に、AhgFLCの発現量の季節推移を分析 しました。すると、12月にゆるやかに 減り始め、 $2 \sim 3$ 月にかけて最小になり (すなわちブレーキがゆるむ)、4〜 5 月 に向かってゆるやかに増え、その後、夏 の間は高く保たれ、再び冬までにゆる やかに減る、といったサイクルの繰り返 しであることがわかりました。つまり、 AhgFLC は季節のおおまかな温度変化に 応答して調節されているようだというこ とがわかりました。

さらに、調査地の気温デー夕を得て、 気温変化とAhgFLC の発現量の変化を、 態学・エコゲノミクス研究を推進している。
生態学で汎用される時系列解析を用いて 解析してみました。「過去一定期間にわ たる、ある一定（閾值）以下の温度を経 験した量で、AhgFLCの発現量が決まる」 という仮説を立て、温度変化の積算と AhgFLC の発現量の関係を「もつともら しく」説明できる間值と期間を計算した のです。その結果、閾値として「10.5 度」 が、期間として「過去 6 週間」という数 值が割り出されました。このときの「もつ ともらしさ」は予想以上に高く、80 パー セントを超えていました。この值は、ほ ぼ完全に説明が付くというレベルです。 私たちにとって驚くべき数值でした。

並行して、実験室の環境管理下でも八 クサンハタザオを育て、同じょうに気 温の変化とAhgFLCの発現の関係を調 べました。その結果、野外では AhgFLC によるブレーキが、実際に必要な值より も強くゆるめられている(遺伝子の発現 が過度に抑制されている) ことがわかり ました。花を咲かせるには細胞分裂やさ まざまな代謝を促進しなくてはならない

\section{工藤 洋}

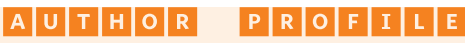
博士 (理学) を取得。日本学術桭嬹会海外特別研究員として米国スミソーアン環境研究所 (SERC、1994～1996 年) に留学。その後、東京都立大学（現首都大学東京）大学院理 学研究科助手 (1996 2002 年)、神戸大学大学院理学研究科准教授（2002～2008 年) を経て、2008 年、京都大学生態学研究センター教授に着任。野生植物を対象に、分子生

ので、ある程度の温度が必要です。とこ ろが、春に暖かくなって AhgFLCによ るブレーキがすぐに効いてしまうと、花 成を進めることが難しくなります。ブ レーキを過度にゆるめておくことで、気 温が上がってきたからといってすぐに花 成が終了しないようにし、その間に花の 細胞分裂や分化を進めるのではないかと 考えられます。

植物の新たな能力が解明できたわ けですね。

そのとおりです。まだ詳細な検証はして いませんが、温度変化の情報は「AhgFLC 遺伝子周辺にある分子の状態」を変え ることで記憶しているのではないかと考 えています。遺伝子を束ねるタンパク質 （ヒストン）が㠜集すると遺伝子の発現 (mRNAへの転写) が抑制され、ゆるむ と充進する仕組み (エピジェネティック制 御）が知られていますが、ハクサンハ夕 ザオの AhgFLCでは、こうした機構が温 度に反応して働いているのだと思います。

今後は、研究をさらに進め、一見何の 変化もないようにみえる冬眠中の植物の 状態変化を遺伝子発現の変化で解析する モデルを作りたいと考えています。完成 すれば、分子メカニズムに基づくモデル として、生息場所や植物種を問わずに開 花予測に応用でき、農業や園芸、温暖化 に対する植物の応答の予測などにも役立 つと思います。

聞き手は、西村尚子（サイエンスライター）。

1. Aikawa,S., Kobayashi,M.J., Satake, A., Shimizu,K.K. and Kudoh,H. PNAS Early Edition (2010) 